\title{
Penerapan Model Pembelajaran Inkuiri Terbimbing untuk Meningkatkan Kemampuan Berpikir Kritis Peserta Didik
}

\section{The Implementation of Guided Inquiry Learning to Improve Student's Critical Thinking Ability}

\author{
Siska Ernawati ${ }^{*}$, Yudi Rinanto ${ }^{1}$, Marjono $^{1}$ \\ ${ }^{1}$ Pendidikan Biologi, Fakultas Keguruan dan Ilmu Pendidikan, Universitas Sebelas Maret. Jl. Ir. Sutami No.36A, Jebres, Kota Surakarta, \\ Jawa Tengah 57126, Indonesia \\ *Corresponding authors: siskaernawati15@gmail.com
}

Manuscript received: ......... Revision accepted:

\begin{abstract}
The research aimed to improve students' critical thinking ability through the implementation of guided inquiry learning. The research was a Classroom Action Research conducted in three cycles. Each cycle consisted of four stages: planning, acting, observing, and reflecting. Subject of the research was the second grader at science 3 class SMAN 6 Surakarta academic year 2014/2015, consisting of 14 boys and 19 girls. Data collecting techniques used in this research were essay test, observation, and interview, which data validation using triangulation technique. Essay test that used in this reasearch containing six aspects of critical thinking ability: interpretation, analysis, evaluation, inference, explanation, and selfregulation. Data were analyzed using descriptive qualitative technique. Spiral model were used for the research procedure. The result of the research showed that each aspect of critical thinking ability increased within three cycles of guided inquiry learning implementation. Interpretation increased 30,30\%; analysis 36,36\%; evaluation $41,67 \%$; inference $31,82 \%$; explanation $37,88 \%$; and self-regulation $24,25 \%$.

Based on the data analysis result, it can be concluded that the implementation of guided inquiry learning is able to improve students' critical thinking ability of second grader at science 3 class SMAN 6 Surakarta academic year 2014/2015. .
\end{abstract}

Keywords: guided inquiry learning, critical thinking

\section{PENDAHULUAN}

Pembelajaran merupakan proses pendidikan yang memberikan kesempatan kepada peserta didik untuk mengembang-kan potensi mereka menjadi kemampuan yang diperlukan untuk hidup dan bermasyarakat (Depdikbud, 2013). Belajar merupakan proses mental untuk mengkonstruksi pengetahuan dan keterampilan peserta didik (Sani, 2013). Hasil dari belajar adalah perubahan tingkah laku, konsepsi dan kemampuan berpikir. Kemampuan berpikir menjadikan peserta didik mampu membangun pengetahuannya sendiri dan meningkatkan pemahaman konseptual. Salah satu kemampuan berpikir yang perlu dikembangkan adalah kemampuan berpikir kritis. Berpikir kritis terutama penting pada masa sekarang karena peserta didik diekspos secara berkelanjutan dengan informasi dari saluran televisi, situs, dan jejaring sosial yang belum diperiksa akurasinya. Berpikir kritis diperlukan untuk memilah mana yang bernilai dari sekian banyak gagasan dan mempertimbangkan apakah suatu informasi diterima atau ditolak (Bono, 2007).

Hasil observasi pada pembelajaran Biologi di kelas XI MIPA 3 SMAN 6 Surakarta Tahun Pelajaran 2014/2015 menunjukkan pembelajaran yang dilaksana-kan secara ceramah. Aktivitas peserta didik selama pembelajaran adalah menyalin materi yang ditulis guru ke dalam buku catatannya dan tidak tampak aktivitas bertanya. Peserta didik cenderung pasif selama kegiatan pembelajaran.
Peserta didik menjawab pertanyaan guru secara singkat dan kurang mampu mengembangkan gagasan dengan bahasa sendiri. Peserta didik yang menjawab pertanyaan didominasi oleh peserta didik tertentu.

Partisipasi peserta didik dalam mengutarakan pendapat dan pertanyaan selama pembelajaran merupakan refleksi dari kondisi pembelajaran, ketertarikan dan rasa ingin tahu peserta didik. Menurut Thompson (2011), karakteristik seseorang yang berpikir kritis yaitu selalu ingin tahu, memiliki alasan yang meyakinkan, bersikap terbuka, jujur, fleksibel, menilai secara objektif dan bijaksana, bersedia untuk mempertimbangkan kembali suatu per-nyataan, rajin dalam mencari tahu informasi yang relevan dan mencari jawaban atau kebenaran, sehingga hasil observasi terhadap peserta didik selama pembelajaran memperlihatkan bahwa peserta didik kurang menunjukkan karakteristik sebagai seorang yang berpikir kritis.

Berpikir kritis merupakan pemikiran yang masuk akal dan reflektif yang berfokus untuk memutuskan apa yang dipercaya atau dilakukan (Ennis, 2008). Berpikir kritis merupakan proses yang terarah dan jelas yang digunakan dalam kegiatan mental seperti memecahkan masalah, mengambil keputusan, menganalisis asumsi dan melakukan penyelidikan ilmiah. Berpikir kritis dapat melatih peserta didik untuk meng-identifikasi masalah secara sistematis, mengatasi masalah secara terorganisir, 
merumuskan pertanyaan yang inovatif, dan merancang solusi orisinil (Johnson, 2009).

Menurut Facione (2011), berpikir kritis terdiri dari enam aspek yaitu: 1) Interpretasi, kemampuan untuk menyatakan arti dari berbagai pengalaman, situasi, data, prosedur atau kriteria; 2) Analisis, kemampuan mengidentifikasi maksud dan hubungan antar pernyataan, pertanyaan, konsep, deskripsi atau bentuk representasi lainnya; 3) Evaluasi, kemampuan dalam menilai kredibilitas dan kekuatan logis suatu pernyataan; 4) Inferensi, kemampuan dalam mengidentifikasi unsur-unsur untuk menarik kesimpulan dan hipotesis; 5) Penjelasan, kemampuan menyatakan hasil penalaran berdasarkan bukti, konsep, metodologi dan kriteria tertentu; dan 6) Pengaturan diri, merupakan kesadaran seseorang untuk memonitor proses berpikirnya dengan maksud untuk mempertanyakan, menegaskan, atau mengoreksi suatu pendapat atau hasil yang dicapainya.

Tes kemampuan berpikir kritis Pratindakan dilakukan dengan memberikan soal uraian sesuai dengan aspek berpikir kritis Facione (2011). Hasil tes menunjuk-kan bahwa peserta didik kelas XI MIPA 3 SMAN 6 Surakarta tergolong kurang kritis dengan capaian tiap aspek yaitu: interpretasi $40,15 \%$; analisis $34,85 \%$; inferensi $47,73 \%$; evaluasi $25,00 \%$; penjelasan $30,30 \%$; dan pengaturan diri $42,42 \%$

Atas dasar hasil observasi dan tes Pratindakan, maka perlu dilakukan upaya untuk meningkatkan kemampuan berpikir kritis peserta didik salah satunya melalui penerapan model pembelajaran inkuiri terbimbing. Model pembelajaran inkuiri terbimbing merupakan pembelajaran inkuiri dengan bimbingan tim instruksional yang membantu peserta didik memperoleh pemahaman yang lebih mendalam melalui penggunaan berbagai sumber informasi (Kuhlthau, Maniotes \& Caspari, 2007).

Pembelajaran inkuiri merupakan rangkaian kegiatan pembelajaran yang menekankan pada proses berpikir kritis dan analitis sebagai bagian dari proses mental untuk mencari dan menemukan sendiri jawaban dari suatu masalah yang dipertanyakan (Hosnan, 2014). Pembelajaran inkuiri mendorong peserta didik berpikir dan bekerja atas inisiatif sendiri, membantu peserta didik mengembangkan konsep diri yang positif, mengembangkan ide untuk menyelesaikan tugas dengan caranya sendiri, dan menghindarkan peserta didik dari cara

$$
\text { Capaian }(\%)=\ldots \text { Skor } \_ \text {_ } \times 100 \%
$$$$
\sum \text { Skor Maksimal }
$$

Menurut Sahfriana, Subchan \& Suratno (2015), capaian kemampuan berpikir kritis peserta didik dapat dikategorikan sebagai berikut: $0-20 \%$ tidak kritis; $21 \%$ 40\% kurang kritis; 41\%-60\% cukup kritis; 61\%-80\% kritis; dan $81 \%-100 \%$ sangat kritis. Target penelitian adalah adanya peningkatan kemampuan berpikir kritis peserta didik menjadi kategori kritis, sehingga siklus tindakan belajar menghafal (Amri \& Ahmadi, 2010). Pembelajaran inkuiri dibutuhkan karena pembelajaran sains tidak hanya sekedar mengingat fakta dan informasi ilmiah, tetapi lebih kepada pemahaman dan penerapan konsep dan metode ilmiah (Bell, dkk., 2010).

Menurut Kitot, Ahmad \& Seman (2010), penerapan pembelajaran inkuiri secara efektif dapat meningkatkan kemampuan berpikir kritis peserta didik dibanding pembelajaran tradisional yang bersifat teacher-centered. Inkuiri terbimbing menjadikan peserta didik terbiasa mengkaji suatu permasalahan melalui kegiatan hands-on, minds-on dan socials-on. Tahapan pembelajaran inkuiri menurut Scott, Tomasek \& Matthews (2010) meliputi observasi, merumuskan masalah, merumus-kan hipotesis, merancang dan melakukan investigasi, analisis data, dan argumentasi.

Berdasarkan permasalahan di kelas XI MIPA 3 SMAN 6 Surakarta Tahun Pelajaran 2014/2015, maka dilakukan penelitian yang bertujuan untuk meningkat-kan kemampuan berpikir kritis peserta didik melalui penerapan model pembelajaran inkuiri terbimbing.

\section{METODE PENELITIAN}

Metode penelitian menggunakan Penelitian Tindakan Kelas. Prosedur penelitian berupa model spiral yang terdiri dari empat tahap dalam satu siklus yaitu: perencanaan, pelaksanaan, observasi, dan refleksi, yang seterusnya berputar kembali sampai target yang diharapkan tercapai (Uno, Lamatenggo \& Koni, 2012).

Subjek penelitian adalah peserta didik kelas XI MIPA 3 SMAN 6 Surakarta Tahun Pelajaran 20014/2015 dengan jumlah 33 peserta didik yang terdiri dari 14 putra dan 19 putri. SMAN 6 Surakarta beralamat di Jalan Mr. Sartono No 30.

Data penelitian berupa kemampuan berpikir kritis peserta didik yang diperoleh melalui teknik tes, observasi, dan wawancara. Validitas data menggunakan triangulasi teknik. Pembahasan dilakukan dengan metode analisis deskriptif kualitatif.

Instrumen penelitian berupa tes uraian berjumlah 6 butir soal yang masing-masing mewakili tiap aspek kemampuan berpikir kritis Facione (2011). Rumus capaian tiap aspek kemampuan berpikir kritis adalah sebagai berikut (Sahfriana, Subchan \& Suratno, 2015):

dihentikan apabila tiap aspek kemampuan berpikir kritis telah meningkat menjadi $61 \%$. 
HASIL DAN PEMBAHASAN

Hasil tindakan berupa capaian tiap aspek kemampuan berpikir kritis dari dapat dilihat pada Gambar 1 .

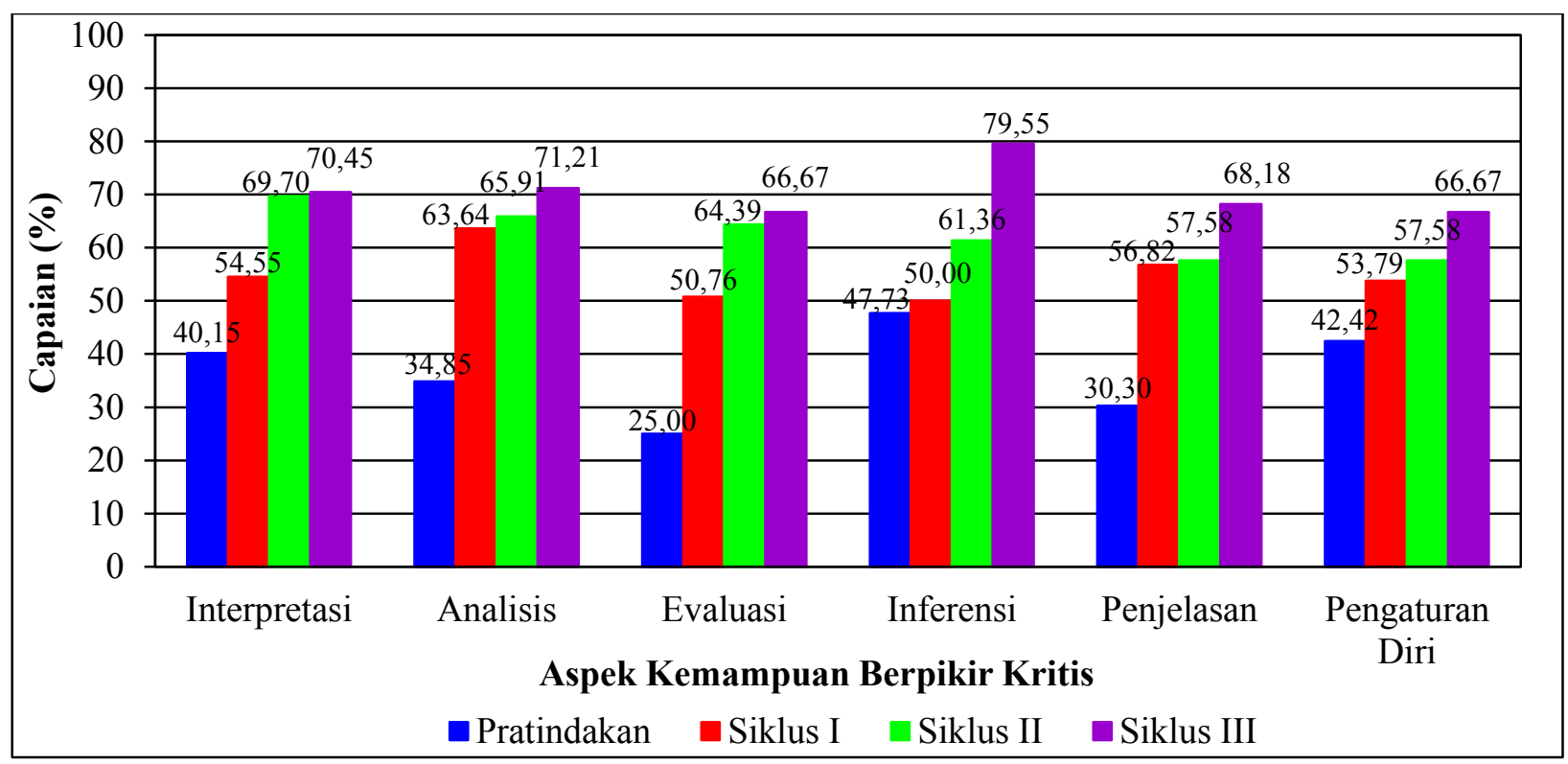

Gambar 1. Diagram Capaian Tiap Aspek Kemampuan Berpikir Kritis pada Tiap Siklus

Gambar 1 menunjukkan adanya peningkatan tiap aspek kemampuan berpikir kritis dari Pratindakan, Siklus I, Siklus II, dan Siklus III dengan penerapan pem-belajaran inkuiri terbimbing. Pembelajaran inkuiri memberikan kesempatan kepada peserta didik untuk berpikir dan berpartisipasi penuh dalam pembelajaran sehingga dapat meningkatkan pemahaman proses dan rasa ingin tahu peserta didik (Opara \& Oguzor, 2011). Menurut Bell, dkk. (2010), model pembelajaran inkuiri mengakomodasi proses pembelajaran yang mendorong peserta didik untuk melakukan aktivitas ilmiah, bertanya dan berpendapat dalam rangka membangun pengetahuannya sendiri sesuai dengan teori belajar konstruktivisme, sehingga dapat meningkat-kan kemampuan berpikir kritis peserta didik.

\section{Aspek Interpretasi}

Aspek interpretasi terutama terlatihkan pada tahap observasi dan tahap melaksanakan investigasi. Tahap observasi dilakukan peserta didik melalui kegiatan pengamatan terhadap fenomena yang disajikan. Misalnya pada Siklus I ditampil-kan gambar dua bayi berpenampilan serupa, kemudian peserta didik mengamati dan menyampaikan pendapat mengenai cara membedakan jenis kelamin kedua bayi. Peserta didik menyampaikan banyak gagasan, seperti kedua bayi hanya dapat dibedakan jenis kelaminnya berdasarkan organ reproduksinya saja karena ciri kelamin sekunder pada bayi belum berkembang. Aspek interpretasi terlatihkan ketika peserta didik mengungkapkan pendapat tentang apa yang diamatinya secara logis dan sesuai kenyataan.

Tahap melakukan investigasi di-lakukan peserta didik melalui pengamatan torso dan gambar. Misalnya pada Siklus III peserta didik mengamati grafik siklus menstruasi, kemudian peserta didik meng-ungkapkan bahwa ketika hormon LH meningkat maka akan mendorong terjadinya ovulasi. Aspek interpretasi terlatihkan ketika peserta didik mampu memahami dan mengungkapkan makna dari grafik yang diamatinya.

Aspek interpretasi pada Siklus I belum mencapai target penelitian. Berdasar-kan wawancara dengan peserta didik setelah Siklus I, diketahui bahwa materi organ reproduksi masih dianggap tabu oleh beberapa peserta didik sehingga mengurangi motivasinya untuk melakukan pengamatan dan mengajukan pertanyaan secara lebih detail dan mendalam.

Pengamatan yang dilakukan peserta didik pada Siklus II berkaitan dengan proses pembentukan sel kelamin dan pada Siklus III mengenai siklus menstruasi dan fertilisasi. Pada Siklus II dan III peserta didik lebih nyaman dalam melakukan kegiatan pengamatan dan investigasi, sehingga peserta didik lebih mudah dalam membangun pemahaman dan menyatakan arti dari pengamatannya. Hasilnya capaian aspek interpretasi telah melebihi target pada Siklus II dan III. Peningkatan aspek interpretasi dari Pratindakan ke Siklus III sebesar 30,30\%.

\section{Aspek Analisis}

Aspek analisis terutama terlatihkan pada tahap analisis data. Tahap analisis data dilakukan peserta didik melalui 
kegiatan diskusi. Peserta didik dalam kelompok mencari hubungan antara data yang diperoleh dengan teori.

Aspek analisis telah melebihi target penelitian pada Siklus I. Berdasarkan hasil wawancara, peserta didik menyatakan bahwa dengan kegiatan diskusi kelompok membantu peserta didik dalam menganalisis suatu permasalahan, terutama ketika peserta didik kesulitan untuk memberikan alasan yang mendukung hasil pengamatannya atau menentukan keterkaitannya dengan teori.

Kegiatan diskusi memberi keuntung-an bagi peserta didik untuk meningkatkan kemampuannya dalam memberikan alasan dan mengembangkan argumennya (Thomas, 2011). Diskusi dilakukan dalam kelompok kecil dengan jumlah anggota kelompok empat sampai enam peserta didik. Peserta didik dalam kelompok kecil mempunyai kecenderungan untuk mempelajari materi secara lebih mendalam, memungkingkan interaksi antar peserta didik yang lebih dekat, dan peserta didik juga mempunyai kesempatan berpendapat yang lebih besar.

\section{Aspek Evaluasi}

Aspek evaluasi terutama terlatihkan pada tahap analisis data dan argumentasi. Misalnya pada Siklus II, setelah melakukan pengamatan terhadap struktur sel sperma, peserta didik mengajukan pertanyaan apakah benar struktur sel sperma selalu demikian. Peserta didik kemudian memeriksa ke-benarannya dengan membaca referensi dan saling berpendapat mengenai kemungkinan adanya kelainan struktur sperma misalnya sperma dengan ekor pendek atau tidak memiliki ekor dan faktor yang mempengaruhi kelainan struktur sperma. Evaluasi ditandai dengan aktivitas peserta didik untuk mempertimbangkan, menolak atau menerima pendapat peserta didik lain dengan saling memeriksa kebenarannya.

Capaian aspek evaluasi mengalami peningkatan pada tiap siklus tindakan, namun pada Siklus I belum mencapai target penelitian. Berdasarkan hasil wawancara, beberapa peserta didik menyatakan kesulitan dalam menilai kebenaran suatu pernyataan atau pendapat karena peserta didik kurang memahami kata-kata ilmiah dan belum paham betul mengenai teori yang berkaitan dengan pernyataan yang diungkapkan. Peserta didik cenderung menilai hanya berdasarkan pengalamannya saja tanpa teori yang mendukung.

Peserta didik pada pembelajaran siklus selanjutnya dibimbing untuk lebih menggunakan sumber belajar seperti buku dalam menilai dan memeriksa kebenaran suatu pendapat, sehingga alasan yang diberikan lebih meyakinkan. Peserta didik juga mulai terbiasa untuk melakukan diskusi dengan mengutarakan berbagai pendapat dan berpikir dari berbagai sudut pandang sehingga dapat membantu peserta didik untuk berpikir secara lebih baik. Pelaksana-an kegiatan diskusi yang lebih baik pada pembelajaran Siklus II dan III mendorong peningkatan kemampuan mengevaluasi sehingga diperoleh peningkatan capaian dari Pratindakan ke Siklus III sebesar $41,67 \%$.

\section{Aspek Inferensi}

Inferensi merupakan bagian dari kerja ilmiah. Kerja ilmiah tersebut dapat dibelajarkan melalui inkuiri yaitu dengan kegiatan merumuskan hipotesis, merancang investigasi dan menarik kesimpulan.

Kemampuan merumuskan hipotesis merupakan salah satu bagian dari aspek inferensi menurut Facione (2011), sehingga dengan terlibat langsung dalam kegiatan merumuskan hipotesis dapat melatih peserta didik untuk melakukan inferensi.

Inferensi juga dimunculkan dengan memberi kesempatan kepada peserta didik untuk membuat kesimpulan dari materi dan kegiatan penyelidikan yang telah peserta didik pelajari dan lakukan. Kesimpulan ditarik dengan mempertimbangkan hasil pe-nyelidikan dan kajian teori yang dilakukan melalui kegiatan diskusi kelompok.

Inferensi tidak hanya sekedar pe-narikan kesimpulan, tetapi juga memutuskan secara tepat berdasarkan pengetahuan dan informasi faktual. Pada tahap merancang investigasi, inferensi dilatihkan ketika peserta didik menentukan strategi pe-nyelidikan yang tepat dan masuk akal untuk memperoleh suatu informasi. Misalnya untuk mengetahui proses fertilisasi, maka penyelidikan dapat dilakukan dengan pe-ngamatan terhadap gambar dan video proses fertilisasi.

Capaian aspek inferensi pada Siklus I belum mencapai target penelitian. Berdasarkan observasi pada pelaksanaan pembelajaran Siklus I, peserta didik terlihat ragu-ragu dan cenderung mengungkapkan hipotesis secara serempak sehingga kemampuan inferensi tidak terlatihkan secara maksimal. Berdasarkan hasil wawancara, peserta didik menyatakan dapat menarik kesimpulan dari penyelidikan yang dilakukan, tetapi masih merasa kesulitan untuk menarik kesimpulan dari wacana ilmiah karena tidak terbiasa dengan bahasa ilmiah yang digunakan dalam wacana.

Aspek inferensi pada Siklus II telah melebihi target penelitian. Pada Siklus II, peserta didik dibimbing untuk menarik kesimpulan yaitu dengan menggarisbawahi pernyataan atau informasi penting dalam suatu wacana. Pembelajaran inkuiri yang dilakukan secara kontinyu dapat melatih peserta didik untuk terbiasa melakukan aktivitas ilmiah seperti merumuskan hipotesis, merancang investigasi dan menarik kesimpulan sehingga dapat meningkatkan kemampuan inferensi peserta didik. Peningkatan capaian dari Pratindakan ke Siklus III adalah $31,82 \%$.

\section{Aspek Penjelasan}

Peningkatan capaian aspek penjelas-an dari Pratindakan ke Siklus III adalah 37,88\%. Aspek penjelasan terutama terlatih-kan dalam analisis data dan argumentasi.

Penjelasan berawal dari kegiatan pengamatan yang dilakukan peserta didik. Pada tahap analisis data, peserta didik diminta untuk memberikan penjelasan mengenai hasil pengamatan yang diperoleh dari kegiatan penyelidikan. Penjelasan juga dilakukan dengan memberikan penalaran berupa alasan logis terhadap suatu pernyataan ataupun 
pertanyaan disertai teori yang mendukung, misalnya pada Siklus II peserta didik memberi penjelasan tentang apa yang dimaksud dengan menopause dan mengapa perempuan dapat mengalami menopause dikaitkan dengan oogenesis.

Aspek penjelasan mengalami peningkatan capaian pada tiap siklus tindakan, namun baru mencapai target penelitian pada Siklus III. Berdasarkan hasil wawancara, peserta didik menyatakan tidak kesulitan untuk memberikan deskripsi, definisi istilah ataupun alasan, hanya saja peserta didik kurang membaca sehingga alasan yang diberikan sering kali tidak didukung oleh teori. Berdasarkan observasi selama kegiatan diskusi pada pembelajaran Siklus I dan II, peserta didik cenderung mengungkapkan pendapat hanya berdasar-kan pengalaman atau fakta yang diamati saja, sehingga peserta didik kurang optimal dalam memberikan penjelasan.

\section{Aspek Pengaturan Diri}

Penerapan pembelajaran inkuiri mulai dari tahap observasi hingga tahap argumentasi dapat melatih peserta didik untuk melakukan pengaturan diri karena pembelajaran inkuiri memberi kesempatan kepada peserta didik untuk terlibat langsung dalam pembelajaran. Pembelajaran inkuiri menjadikan peserta didik mandiri dan bertanggung jawab atas proses belajarnya sendiri.

Peserta didik belajar dengan meng-observasi peserta didik lain dan saling berinteraksi dalam kegiatan kelompok. Kegiatan diskusi pada tahap analisis data dapat melatih peserta didik untuk saling memeriksa kebenaran pernyataan peserta didik lain sehingga secara tidak langsung juga membantu membenarkan konsepnya sendiri. Pengaturan diri dapat secara efektif dilatih ketika peserta didik menunjukkan reaksi positif terhadap pembelajaran.

Aspek pengaturan diri mengalami peningkatan capaian pada tiap siklus tindakan, namun capaian pada Siklus I dan II belum mencapai target penelitian. Ber-dasarkan observasi pada proses pembelajar-an, beberapa peserta didik terlihat kurang fokus pada tahap analisis data yang ditandai dengan saling membicarakan topik di luar materi pembelajaran. Beberapa peserta didik juga masih menyelesaikan lembar kerjanya ketika peserta didik lain melakukan presentasi pada tahap argumentasi. Berdasarkan wawancara dengan peserta didik setelah pelaksanaan Siklus I, diketahui bahwa ada beberapa peserta didik yang tidak turut bekerja dalam kegiatan kelompok.

Temuan permasalahan pada pembelajaran Siklus I dan II menunjukkan bahwa peserta didik kurang optimal dalam melakukan pengaturan diri, sehingga aspek pengaturan diri mengalami peningkatan paling rendah dibanding aspek lainnya dengan peningkatan capaian dari Pratindak-an ke Siklus III adalah 24,25\%.

Pengaturan diri peserta didik dalam pembelajaran merupakan kesadaran peserta didik untuk memonitor proses berpikir, perilaku dan emosinya sendiri dalam melakukan tugas sehingga dapat mencapai tujuan belajarnya. Peserta didik harus dapat mengontrol perhatiannya, termasuk untuk menghilangkan hal-hal diluar topik pembelajaran yang mengganggu pikirannya selama pembelajaran berlangsung. Peserta didik juga harus mampu mengatur waktu dalam menyelesaikan tugasnya sehingga dapat mencapai tujuan belajar secara efektif. Guru dapat membantu peserta didik dengan memberikan bimbingan dalam tiap tahapan pembelajaran sehingga peserta didik dapat menciptakan keterampilan dan kebiasaan belajar yang lebih baik.

Kemampuan berpikir kritis peserta didik mengalami peningkatan pada tiap siklus tindakan. Salah satu faktor yang mempengaruhi peningkatan kemampuan berpikir kritis adalah kualitas pembelajaran yang semakin baik. Guru melakukan perbaikan pembelajaran pada tiap siklus melalui tahap refleksi dan perencanaan kembali sebagai upaya perbaikan untuk siklus berikutnya, sehingga capaian tiap aspek kemampuan berpikir kritis menjadi lebih tinggi.

\section{KESIMPULAN}

Berdasarkan hasil penelitian dapat disimpulkan bahwa penerapan model pembelajaran inkuiri terbimbing dapat meningkatkan kemampuan berpikir kritis peserta didik kelas XI MIPA 3 SMAN 6 Surakarta Tahun Pelajaran 2014/2015. Persentase peningkatan tiap aspek kemampuan berpikir kritis yaitu: aspek interpretasi 30,30\%; aspek analisis 36,36\%; aspek evaluasi 41,67\%; aspek kesimpulan $31,82 \%$; aspek penjelasan $37,88 \%$; dan aspek pengaturan diri $24,25 \%$.

\section{DAFTAR PUSTAKA}

Amri, S. \& Ahmadi, I. (2010). Proses Pembelajaran Kreatif dan Inovatif dalam Kelas. Jakarta: Prestasi Pustaka.

Bell, T., Urhahne, d., Schanze, S., \& Ploetzner, R. (2010). Collaborative Inquiry Learning: Models, Tools, and Challenges. International Journal of Science Education, 32 (3), 349-377.

Bono, E. d. (2007). Revolusi Berpikir: Mengajari Anak Anda Berpikir Canggih dan Kreatif dalam Memecahkan Masalah dan Memantik Ide-Ide Baru. Bandung: Penerbit Kaifa.

Depdikbud. (2013). Lampiran IV Peraturan Menteri Pendidikan dan Kebudayaan Republik Indonesia No. 81 A tentang Implementasi Kurikulum Pedoman Umum Pembelajaran. Jakarta: Departeman Pendidikan dan Kebudayaan.

Ennis, R. H. (2008). Nationwide Testing of Critical Thinking for Higher Education: Vigilance. Teaching Philosophy, 31 (1), 1-26.

Facione, P.A. (2011). Critical Thinking: What It Is and Why It Count. Insight Assessment.

Hosnan. (2014). Pendekatan Saintifik dan Kontekstual dalam Pembelajaran Abad 21: Kunci Sukses 
Implementasi Kurikulum 2013. Bogor: Ghalia Indonesia.

Johnson, E. (2009). Contextual Teaching and Learning: Menjadikan Kegiatan Belajar Mengajar Mengasyikkan dan Bermakna. Bandung: Mizan Learning Center.

Kitot, A.K.A., Ahmad, A.R., \& Seman, A.A. (2010). The Effectiveness of Inquiry Teaching in Enhanching Students' Critical Thinking. Social and Behavioral Sciences, 7(c), 264-273.

Kuhlthau, C.C., Maniotes, L.K., \& Caspari, A.K. (2007). Guided Inquiry: Learning in the 21st Century. London: Libraries Unlimited.

Opara, J.A. \& Oguzor, N.S. (2011). Inquiry Instructional Method and the School Science Curriculum. Journal of Social Sciences, 3 (3), 188-198.

Sahfriana, I., Subchan, W., \& Suratno. (2015). Penerapan Model Pembelajaran Group Investigation (GI) dalam Meningkatkan Kemampuan Berpikir Kritis dan Keterampilan Sosial Siswa dalam Pembelajaran IPA Biologi untuk Materi Ajar Pertumbuhan dan Perkembangan Kelas 8-C Semester Gasal di SMP Negeri 1 Bangil Pasuruan. Pancaran, 4 (2), 213-222.

Sani, R.A. (2013). Inovasi Pembelajaran. Jakarta: Bumi Aksara.

Scott, C., Tomasek, T., \& Matthews, C.E. (2010). Thinking Like a Scientist. Science and Children, 38-42.

Thomas, T. (2011). Developing First Year Students' Critical Thinking Skills. Asian Social Science, 7 (4).

Thompson, C. (2011). Critical Thinking Across the Curriculum: Process Over Output. International Journal of Humanities and Social Science, 1 (9).

Uno, H.B., Lamatenggo, N., \& Koni, S.M.A. (2012). Menjadi Peneliti PTK yang Profesional. Jakarta: Bumi Aksara. 